\title{
A STUDY OF ACCESS TO SANITATION PROFILES OF RURAL UPLAND AND COASTAL COMMUNITIES OF AKWA IBOM STATE, NIGERIA
}

\author{
A. J. OKON, M. E. EJA AND R. E. KALU
}

(Received 24 March 2017; Revision Accepted 23 June 2017)

\begin{abstract}
In developing countries, e.g., Nigeria, several communities have limited access to sanitation and sanitation facilities, thus such communities dump their solid and liquid wastes indiscriminately. The aim of this study was to assess access to sanitation, and compare basic sanitation facilities between upland and coastal communities of Akwa Ibom State. With a cross-sectional design, 420 respondents were selected and administered questionnaires to obtain information on sanitation and sanitation facilities of the communities using a multi-stage random sampling technique. Result shows that faecal disposal facilities available for upland and coastal communities were respectively $187(89.05 \%)$ and $98(46.67 \%) .30(26.79 \%)$ of households defecate in open bodies of water in the coastal areas, while upland communities do not. Also, 9(39.13\%) and 64(57.14\%) of upland and coastal areas respectively, defecate in bushes/swamps, while $14(60.87 \%)$ and $18(16.07 \%)$ bury their faeces in pits. On the whole, improved sanitation coverage recorded $61.90 \%$ and $38.10 \%$ respondents for the rural upland and coastal communities respectively, while unimproved sanitation coverage for upland and coastal communities recorded $31.43 \%$ and $68.57 \%$ respectively. This indicates that sanitation facilities and coverage are worse in the rural coastal areas. In conclusion, both upland and coastal communities of Akwa lbom State still lack adequate sanitation, although the upland communities enjoy relatively improved sanitation than the coastal communities.
\end{abstract}

\section{INTRODUCTION}

Sanitation generally refers to the provision of facilities and services for safe disposal of human faeces and urine (Okon, 2016). Eja (2014) also defines sanitation as a system of disposal of solid and liquid wastes in order to maintain public hygiene and thus sanitation is synonymous with public hygiene. Basic sanitation means the lowest-cost technology ensuring hygienic excreta and sullage disposal, and a clean and healthful living environment, both at home and in the neighbourhood of users. In this case, WHO/UNICEF (2006) has classified sanitation facilities into improved and unimproved sanitation facilities. Sanitation facilities include piped-sewer system, septic tank, ventilated-improved (VIP) latrine, pit latrine with slab and composting toilet. However, unimproved sanitation facilities include pit latrine without slab/open pit, bucket hanging toilet/hanging latrine, no facilities or bush or field.

The disposal of untreated human wastes into water or tidal mudflats along the waterfront communities is linked to public health (Bassey, 2008) and this is the major problem facing the Nigerian coastal areas, as evidenced by health records from Akwa lbom State Hospitals' Management Board (2009). This condition predisposes coastal communities to faeco-oral infections transmitted by the consumption of contaminated food and water (Scott and Oni, 2003). That is why some communities may have access to water without access to improved water sources. Access to drinking water means that the source is less than 1 kilometer (30 minutes round trip) away from its place of use, and might be possible to obtain at least 20 litres per member of a household per day (Okon,

A. J. Okon, Department of Public Health, University of Calabar, Calabar, Cross River State, Nigeria.

M. E. Eja, Department of Biological Sciences, Cross River University of Technology, P.M.B. 1123, Calabar, Nigeria.

R. E. Kalu, Federal Medical Centre, Yenogoa, Bayelsa State, Nigeria. 
2016). Improved sanitation facility is one that hygienically separates human excreta from human contact (Okon, 2016).

The problem of inadequate sanitation is global, although most developed countries have achieved appropriate sanitation coverage. Approximately 2.4 billion people globally do not have access to any type of improved sanitation facility, and about 2 million people die every year due to diarrhoeal diseases, most of them being children less than 5 years of age (FGN?UNICEF, 1997). The most affected are the populations in developing countries living in extreme conditions of poverty (FGN, 2000; Eja et al., 2006). UN-GLAAS (2012) has stated that providing access to safe drinking water and sanitation facilities for excreta disposal with sound hygiene behaviours, is of vital importance to reduce the burden of diseases caused by these risk factors.

Because of limited access to sanitation facilities, people in rural communities defecate indiscriminately causing their water sources to be contaminated. The microorganisms that cause infections occur in the excreta of infected people or animals, and surface water becomes contaminated (Ogbonna, D. N., Igbenijie, M. and Isirimah, N. O., 2006). The rural upland and coastal communities also dump their wastes indiscriminately in nearby bushes, resulting in environmental pollution with consequential epidemics.

The aim of this study, therefore, was to assess access to sanitation, and compare basic sanitation facilities between upland and coastal communities of Akwa Ibom State.

\section{MATERIALS AND METHODS}

\section{Study Area}

The area of study is Akwa Ibom State, which is located at the coastal South-southern part of Nigeria, and lying between latitudes $4^{\circ} 321^{\prime \prime}$ and $5^{\circ} 331^{\prime \prime}$ North, and longitudes $7^{\circ} 251^{\prime \prime}$ and $8^{\circ} 251^{\prime \prime}$ East (Okon, 2016). It covers a total land area of $7,249 \mathrm{~km}^{2}$ with a 2006 Nigerian National Population Census of 3,902,051 people (Figure

1).

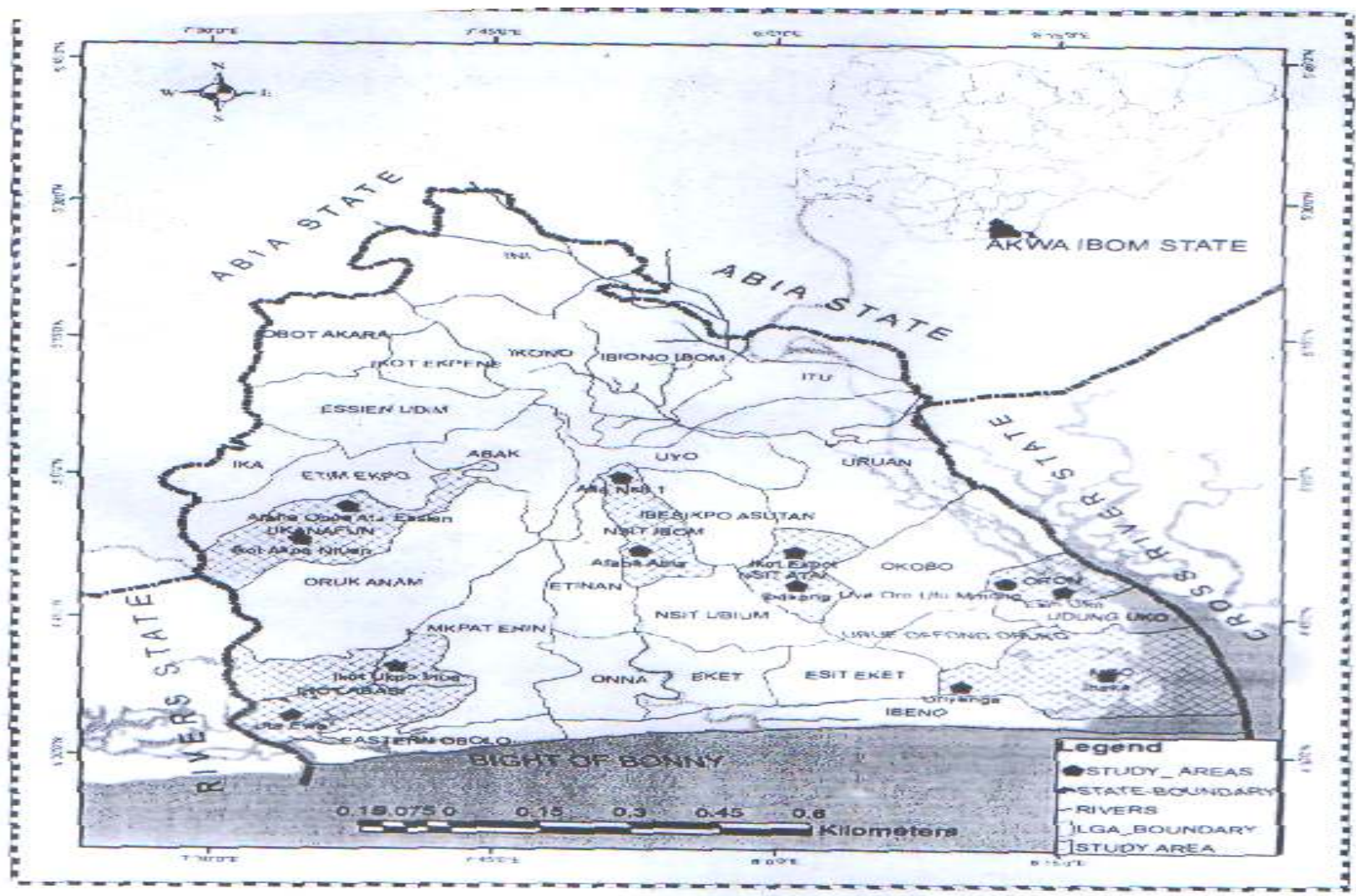

Fig. 1: Map of Akwa Ibom State showing study areas (Source: Department of Geography and Regional Planning, University of Uyo, Nigeria) 
Over $70 \%$ of the people live in the rural areas.

The population is evenly distributed except in vast areas of permanent swamps and coastal areas which are sparsely populated (Directorate of Statistics, 2013). Based on elevation and distance above sea level, eleven (35\%) out of the 31 Local Government Areas (LGAs) of Akwa lbom State, consist of coastal settlements which are Oron, Mbo, Ibeno, Eket, Onna, Ikot Abasi, Eastern Obolo, Okobo, Esit Eket, Urue Offong Oruko and Udung Uko. The other twenty $(65 \%)$ have upland settlements and include Ini, Ikono, Uruan, Itu, Ibiono Ibom, Ikot Ekpene, Eastern Udim, Etim Ekpo, Obot Akara, Ika, Ukanafun, Oruk Anam, Abak, Etinan, Nsit lbom, Mkpat Enin, Nsit Atai, Ibesikpo Asutan, Nsit Ubium and Uyo.

\section{Study design}

A cross-sectional and analytical study was employed to obtain information on sanitation and sanitation facilities of selected households. A multistage sampling technique was employed for the study. This involved random sampling of three LGAs from coastal and three from upland areas, making a total of six LGAs. Two villages were equally selected from each of the six LGAs, making a total of twelve villages. Further, thirty five households were selected from each of the selected villages, and finally respondents were selected from the households for questionnaire administration.

The study population consisted of household heads or adult members of each household. The study population was determined using the statistical formula given by Lutz (1982), which is $n=Z^{2}(p q) / d^{2}$, where $n$ is minimum sample size, $Z$ is confidence limit (1.96), $p$ is estimated rural population with access to sanitation $(0.47), q$ is $1-p(1-0.47)$ which is $0.53, d$ is the precision which is 0.05 . Therefore, $\mathrm{n}=\frac{1.96^{2} \times 0.47 \times 0.53}{0.05^{2}}=382.8$.

Considering an attrition bias of $5 \%$, i.e., $382.8 / 0.95$, it is equivalent to 402 . To attain the required sample size, 35 households were selected from each of the 12 villages drawn from 3 upland and 3 coastal LGAs respectively, giving a study population of 420 respondents.

\section{Instrument for data collection}

Two questionnaires were developed. One was for the researcher's observation of available sanitation facilities, and the other for the respondents. The questionnaires developed for respondents (household heads) comprised sections (A and B). Section A consisted of close-ended questions on personal data of respondents and section B consisted of households sanitation facilities. As the questionnaires were administered to the respondents, the questions were read out to the respondents and their responses were ticked. All the questionnaires administered were retrieved.

\section{Results}

A summary of sanitation facilities in the study areas is represented in Table 1 . The table shows that $187(89.05 \%)$ and $98(46.6 \%)$ in the upland and coastal communities respectively, had faecal disposal facilities, while $23(10.95 \%)$ in the upland and $112(53.33 \%)$ in the coastal communities had no form of faecal disposal facilities.

The data on the sanitation facility in the rural upland communities showed that $8.02 \%$ of the households with faecal disposal facilities had water closet connected to septic system, $57 \%$ had simple pit latrines with lids over them while $30.48 \%$ had simple latrine without lids over them. In the coastal areas, $25.51 \%$ of the households with faecal disposal facilities had water closet connected to septic system, $2.64 \%$ had pour flush latrine with brick wall super structures, $39.80 \%$ had simple pit latrine with cover and $32.65 \%$ had simple pit latrine without cover. Those without faecal disposal facilities in the upland areas defecate in bush/swamp (39.13\%) or bury faeces in pits $(60.87 \%)$. Those in the coastal communities without faecal disposal facilities defecate into open water bodies $(26.79 \%)$, bush/swamps $(57.14 \%)$ or bury in pits $(16.07 \%)$.

Sanitation coverage in the study areas is represented in Table 2. The table shows improved sanitation facilities for upland and coastal areas, as well as unimproved sanitation facilities for upland and coastal areas of the study areas. In the upland and coastal communities, $61.90 \%$ and $31.43 \%$ of households respectively had improved sanitation facilities. Equally, upland and coastal communities respectively had $38.10 \%$ and $68.57 \%$ of households with unimproved sanitation facilities. 
Table 1: Summary of sanitation facilities in study areas

\begin{tabular}{|c|c|c|c|c|c|}
\hline \multirow[b]{2}{*}{1.} & \multirow{2}{*}{$\begin{array}{l}\text { Faecal disposal facility } \\
\text { Availability of faecal disposal facility } \\
\text { Faecal disposal facility available } \\
\text { Faecal disposal facility not available } \\
\text { Total }\end{array}$} & \multicolumn{2}{|c|}{$\begin{array}{l}\text { Communities/response frequency } \\
\text { Upland areas }\end{array}$} & \multicolumn{2}{|l|}{ Coastal areas } \\
\hline & & $\begin{array}{l}\text { No. of respondents } \\
187 \\
23 \\
210\end{array}$ & $\begin{array}{l}\% \\
89.05 \\
10.95 \\
100\end{array}$ & $\begin{array}{l}\text { No. of respondents } \\
98 \\
112 \\
\mathbf{2 1 0}\end{array}$ & $\begin{array}{l}\% \\
46.67 \\
53.33 \\
100\end{array}$ \\
\hline 2. & $\begin{array}{l}\text { Types of sanitation facilities } \\
\text { Water closet connected to septic system }\end{array}$ & 15 & 8.02 & 25 & 25.51 \\
\hline & Ventilated improved pit & 0 & 0 & 0 & 0 \\
\hline & Pour flush latrine with brick wall super structure & 0 & 0 & 2 & 2.04 \\
\hline & Simple pit latrine with cover & 115 & 61.49 & 39 & 39.80 \\
\hline & Simple pit latrine without cover & 57 & 30.48 & 32 & 32.65 \\
\hline & Total & 187 & 100 & 98 & 100 \\
\hline 3. & $\begin{array}{l}\text { Alternative faecal disposal method } \\
\text { Defecating into open water bodies } \\
\text { Defecating in bush/swamp } \\
\text { Burying in pits } \\
\text { Total }\end{array}$ & $\begin{array}{l}0 \\
9 \\
14 \\
23\end{array}$ & $\begin{array}{l}0 \\
39.13 \\
60.87 \\
100\end{array}$ & $\begin{array}{l}30 \\
64 \\
18 \\
112\end{array}$ & $\begin{array}{l}26.79 \\
57.14 \\
16.07 \\
100\end{array}$ \\
\hline 4. & $\begin{array}{l}\text { Disposal of children's faeces } \\
\text { Toilet } \\
\text { Waste bin } \\
\text { Bush } \\
\text { Burying in pits } \\
\text { Stream/river } \\
\text { No children } \\
\text { Total }\end{array}$ & $\begin{array}{l}63 \\
0 \\
29 \\
43 \\
0 \\
75 \\
210\end{array}$ & $\begin{array}{l}30 \\
0 \\
13.81 \\
20.48 \\
0 \\
35.71 \\
100\end{array}$ & $\begin{array}{l}28 \\
0 \\
49 \\
12 \\
62 \\
69 \\
\mathbf{2 1 0}\end{array}$ & $\begin{array}{l}13.33 \\
0 \\
23.33 \\
5.71 \\
29.52 \\
32.86 \\
100\end{array}$ \\
\hline 5. & $\begin{array}{l}\text { Disposal of animal faeces } \\
\text { Bush } \\
\text { Burying in pits } \\
\text { Composting/manure } \\
\text { Waste bin } \\
\text { Allowed where dropped } \\
\text { No animals } \\
\text { Total }\end{array}$ & $\begin{array}{l}61 \\
0 \\
18 \\
0 \\
18 \\
113 \\
\mathbf{2 1 0}\end{array}$ & $\begin{array}{l}29.05 \\
0 \\
8.57 \\
0 \\
8.57 \\
53.81 \\
100\end{array}$ & $\begin{array}{l}36 \\
0 \\
0 \\
0 \\
13 \\
187 \\
\mathbf{2 1 0}\end{array}$ & $\begin{array}{l}17.14 \\
0 \\
0 \\
0 \\
6.19 \\
89.05 \\
100\end{array}$ \\
\hline
\end{tabular}

Table 2: Sanitation coverage in study area

\begin{tabular}{|l|l|l|l|l|l|}
\hline \multicolumn{2}{|l|}{ Improved sanitation facility } & Unimproved sanitation facility \\
\hline Facility type & Upland & Coastal & Facility type & Upland & Coastal \\
\hline $\begin{array}{l}\text { Water } \\
\text { connected to septic } \\
\text { system }\end{array}$ & 15 & 25 & Simple pit latrine without cover & 57 & 32 \\
$\begin{array}{l}\text { Pour flush latrine with } \\
\text { brick wall super } \\
\text { structure } \\
\begin{array}{l}\text { Simple pit latrine with } \\
\text { cover }\end{array}\end{array}$ & - & 2 & Defecating into open water bodies & - & 30 \\
\hline $\begin{array}{l}\text { Total } \\
\text { Percentage(\%) }\end{array}$ & $\mathbf{1 3 0}$ & $\mathbf{6 6}$ & Defecating in bush/swamp & 9 & 64 \\
\hline
\end{tabular}




\section{DISCUSSION}

In this study, faecal disposal facilities available for upland and coastal areas were respectively $187(89.05 \%)$ and $98(46.67 \%)$. Also, alternative faecal disposal methods for upland and coastal areas were respectively as follows: defecating into open water bodies $(0(0 \%)$ and $30(26.79 \%)$; defecating in bush/swamp 9(39.13\%) and $18(16.07 \%)$. This indicates that upland communities had greater access to sanitation than the coastal communities. Also, the data on sanitation coverage in the rural communities showed that $61.90 \%$ of households in the upland areas and $38.10 \%$ in the coastal areas had improved sanitation facilities while $31.43 \%$ ) in the upland and $68.57 \%$ in the coastal areas made use of unimproved sanitation facilities. This indicates that sanitation coverage is worse in the rural coastal areas than the rural upland.

It has been reported by the Akwa Ibom State Hospitals' Management Board (2009) that the dumping of wastes indiscriminately in nearby bushes and drinking water sources impinged on the quality of the drinking water sources resulting in epidemics like cholera, dysentery, typhoid, malaria, among others. The record shows that the cases of persons with water-related diseases between 2007 and 2009 for the coastal areas of Ikot Abasi and Oron were 2,249 and 7,960 respectively, while figures for the upland areas of Mkpat Enin and Etinan were 467 and 7,363 respectively. This agrees with the findings of this study which shows that sanitation coverage is worse in the rural coastal areas than the rural upland. Also, Bassey (2008) reports that the major problems facing the Nigerian coastal environment, for instance, are linked to public health, such as contamination of drinking water. Sanitation infrastructures are less available in the coastal areas than the upland areas, indicating that the upland communities enjoy better health than the coastal communities. This agrees with Addisie (2012) who reported that the availability of improved water supply and sanitation infrastructures are widely recognized as an essential component of human rights, social and economic development.

Currently, global coverage of sanitation is $60 \%$, representing $86 \%$ urban and $38 \%$ rural (Addisie, 2012). This appears to agree with the findings of this study with improved sanitation coverage of $61.90 \%$ and $31.43 \%$ for rural upland and rural coastal areas of Akwa Ibom State, respectively.

Given the risks of faecal contamination of water and the need for proper sanitation practice, more efforts would have to be made to improve environmental cleanliness (WHO/UNICEF, 2015). This is still absent in the upland and coastal communities of Akwa lbom State. It is therefore concluded that both upland and coastal communities of Akwa lbom State still lack adequate sanitation although the upland communities enjoy relatively improved sanitation than the coastal communities.

\section{REFERENCES}

Addisie, M. B., 2012. Assess of Drinking Water Quality and Determinants of Household Potable Water Consumption in Simada District, Ethiopia. Published M.Sc. Research Paper, Cornell University.

Akwa Ibom State Hospital's Management Board., 2009. Reported Cases of Water-related Diseases. Health Records. Akwa Ibom State.

Bassey, S. E., 2008. Environmental Health Status of Some Coastal Settlements in Akwa Ibom State. M.Sc. thesis, University of Uyo, Uyo.

Directorate of Statistics., 2013. Statistical Year Book of Akwa Ibom State of Nigeria. Ministry of Economic Development, Akwa Ibom State.

Eja, M. E., 2014. Water Pollution and Sanitation for Developing Countries. $2^{\text {nd }}$ ed. Seasprint (Nig). Co., Calabar. 200pp.

Eja, M. E., Arikpo, G. E and Akpan, P. A., 2006. An overview of the state of water supply and sanitation in Sub-Saharan Africa: The Nigerian situation. Global J. Env. Sci. 5, (1): 65-70.

FGN., 2000. National Water Supply and Sanitation Policy. Federal Government of Nigeria. $1^{\text {st }}$ ed. Abuja, Nigeria. Pp. 1-3.

FGN/UNICEF., 1997. Master Plan of Operations/Country Programme of Cooperation. 5-20.

Lutz, W., 1982. Sampling: How to select people, households, places to study community health. $3^{\text {rd }}$ ed. International Epidemiology Association. Edinburgh.

Ogbonna, D. N., Igbenijie, M and Isirimah, N. O., 2006. Studies on the inorganic Chemicals and Microbial Contaminants of Health Importance 
in Groundwater Resources in Port Harcourt. J. Appl. Sci. 6:2257-2262.

Okon, A. J., 2016. A study of access and quality of drinking water in rural upland and coastal communities of Akwa Ibom State, Nigeria. A Ph.D. thesis, University of Calabar, Calabar.

Scott, R. E and Oni, O. O., 2003. Towards the Millennium Development Goals - Actions for Water and Environmental Sanitation. Abuja, Nigeria: Proceedings of the $29^{\text {th }}$ WEDC Conference.

UN-GLAAS., 2012. UN-Water GLAAS Annual Assessment of Sanitation and Drinking Water. GLAAS Report. The Challenge of Extending and Sustaining Services. Geneva. WHO Press, 112.
WHO/UNICEF., 2006. Joint Monitoring Programme for Water Supply and Sanitation, WHO and UNICEF. Core Questions on Drinking Water and Sanitation for Household Surveys. WHO Press, World Health Organization, Geneva.

WHO/UNICEF., 2015. WHO/UNICEF JOINT MONITORING PROGRAMME (JMP) for Water Supply and Sanitation. Drinking Water and Sanitation Report and MDG Assessment Report. WHO, Geneva. 